\title{
Organic Hydroxylamine Derivatives. IX.* Structural Analogues of GABA of the Isoxazole Enol-betaine Type. Improved Synthesis and the Crystal Structure of 3-Hydroxy-5-(2-aminoethyl)isoxazole Zwitterion (Homomuscimol)
}

\author{
LOTTE BREHM, POVL KROGSGAARD-LARSEN and HANS HJEDS
}

The Royal Danish School of Pharmacy, Chemical Laboratory C, DK-2100 Copenhagen, Denmark

An improved synthesis and the crystal structure determination of homomuscimol, 3-hydroxy-5(2-aminoethyl)isoxazole zwitterion (IV), which is a structural analogue of $\delta$-aminovaleric acid, are described. The synthesis is based on a reaction sequence in which a carboxylic acid is converted into the corresponding methoxycarbonylamino derivative without isolation of intermediate products. The $\mathrm{p} K_{\mathrm{A}}$ values of homomuscimol have been determined to $5.12 \pm 0.03$ and $9.46 \pm 0.02$.

Crystals of homomuscimol, $\mathrm{C}_{5} \mathrm{H}_{8} \mathrm{~N}_{2} \mathrm{O}_{2}$, are monoclinic, space group $P 2_{1} / n, a=11.530(1)$, $b=6.203(1), c=8.782(2) \AA, \beta=104.20(1)^{\circ}, Z=4$. The structure has been solved by a direct phasing technique using $\mathrm{X}$-ray diffraction data and has been refined by full-matrix least-squares methods. The final $R$ value is 0.042 . The crystal structure is made up of homomuscimol zwitterions and is stabilized by a network of hydrogen bonds.

As part of our investigations of GABA analogues of the isoxazole enol-betaine type $\mathrm{X}$-ray analyses of two crystal forms of muscimol have been performed.1,2 This paper presents an improved synthesis and the crystal structure determination of homomuscimol, 3-hydroxy-5-(2aminoethyl)isoxazole zwitterion (IV). Homomuscimol (IV) is a structural analogue of $\delta$ aminovaleric acid, which exhibits a physiological activity very similar to that of GABA.,4 To our knowledge homomuscimol (IV) has not yet been examined for GABA activity. However, investigations of the biological properties of this compound will be initiated in the near future.

\footnotetext{
* Part VIII. Acta Chem. Scand. 27 (1973) 3251.
}
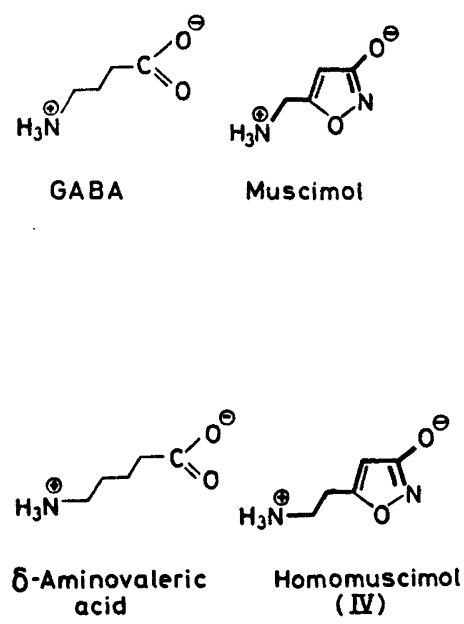

Fig. 1. Some common structural features of GABA/muscimol and $\delta$-aminovaleric acid/homomuscimol.

\section{RESULTS AND DISCUSSION}

Homomuscimol (IV) was synthesized by Bow. den et al..$^{5}$ The preparation described by these authors is based on 3-(3-methoxyisoxazolyl-5)propionic acid (I) and proceeds through several steps, including a Curtius reaction. The reported yield of homomuscimol (IV) is rather low and, since several attempts made at the start of this investigation using the same reaction sequence confirmed this, we were prompted to develop and improve the synthesis. The present synthesis of homomuscimol is also based on 3-(3- 


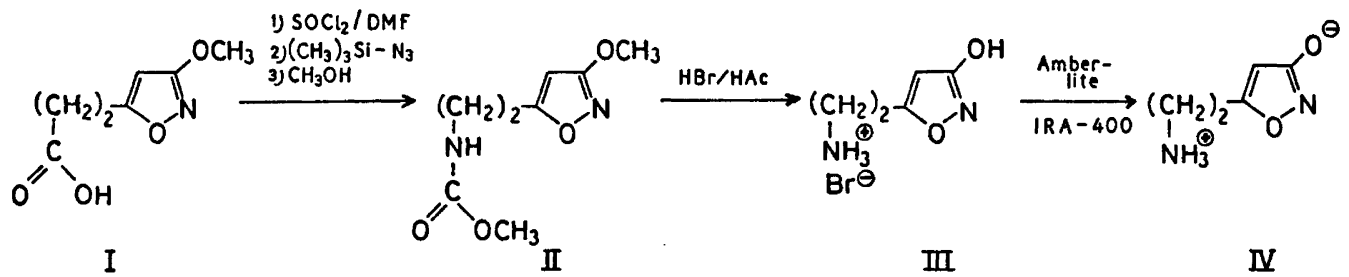

methoxyisoxazolyl-5)propionic acid (I). It is converted into 3-methoxy-5-( $N$-methoxycarbonyl-2-aminoethyl) isoxazole (II) without isolation of intermediate compounds. The reaction is an extension of the general sequence for the preparation of isocyanates, ${ }^{6}$ in which acid chlorides are reacted with trimethylsilyl azide to isocyanates without isolation of the acyl azide intermediates. As the acid chloride of 3-(3-methoxyisoxazolyl-5)propionic acid (I) seemed to be very unstable it is allowed to react with trimethylsilyl azide without purification. The intermediate acyl azide is transformed into the corresponding isocyanate, and the reaction sequence is completed by addition of methanol to the reaction mixture to give 3-methoxy-5( $N$-methoxycarbonyl-2-aminoethyl)isoxazole (II) in good yields. This is then cleaved by hydrogen bromide in glacial acetic acid to give 3-hydroxy-5-(2-aminoethyl)isoxazole hydrobromide (III). Homomuscimol (IV) is isolated from (III) in good yields and in a pure state using a strongly basic ion exchange resin. The stoichiometric $\mathrm{p} K_{\mathrm{A}}$ values of homomuscimol are $5.12 \pm$ 0.03 and $9.46 \pm 0.02$.

The X-ray diffraction analysis of homomus. cimol confirms the zwitterionic structure. The molecular dimensions and the conformation of the molecule are shown in Figs. $2 a$ and $2 b$.
The isoxazole ring is planar within the limits of experimental error; Table 1 lists the displacements of some atoms from the least-squares plane through the ring. The exocyclic oxygen atom $\mathrm{O}(2)$ is in this plane, but the exocyclic carbon atom $\mathrm{C}(6)$ is $0.055 \AA$ out of it. The plane of the aminoethyl side chain makes an angle of $83.1^{\circ}$ with the isoxazole ring plane. The torsion angle $\tau_{1}, \mathrm{O}(1)-\mathrm{C}(5)-\mathrm{C}(6)-\mathrm{C}(7)$, is $\pm 51.7^{\circ}$ and $\tau_{2}, \quad \mathrm{C}(5)-\mathrm{C}(6)-\mathrm{C}(7)-\mathrm{N}(1)$, is $\pm 70.3^{\circ}$. The hydrogen atoms are tetrahedrally

Table 1. Distances of atoms from least squares plane $(\AA)$. The equation of the plane is in direct (unit-cell) space.

Isoxazole ring

Equation: $-3.5282 x+2.9683 y+7.6662 z-$ $3.5116=0$

\begin{tabular}{lrlr}
\hline Atom & Deviation & Atom & Deviation \\
\hline $\mathrm{O}(1)$ & & & \\
$\mathrm{N}(2)$ & $\mathbf{0 . 0 0 2}$ & $\mathrm{C}(6)^{a}$ & $-\mathbf{0 . 0 5 5}$ \\
$\mathrm{C}(3)$ & -0.004 & $\mathrm{C}(7)^{a}$ & $\mathbf{0 . 9 9 3}$ \\
$\mathrm{C}(4)$ & -0.005 & $\mathrm{~N}(1)^{a}$ & $\mathbf{2 . 3 6 1}$ \\
$\mathrm{C}(5)$ & 0.001 & $\mathrm{H}(41)^{a}$ & -0.042 \\
$\mathrm{O}(2)^{a}$ & 0.001 & $\mathrm{H}(61)^{a}$ & -0.015 \\
\hline
\end{tabular}

$a$ These atoms were not included in the calculation of the least squares plane.
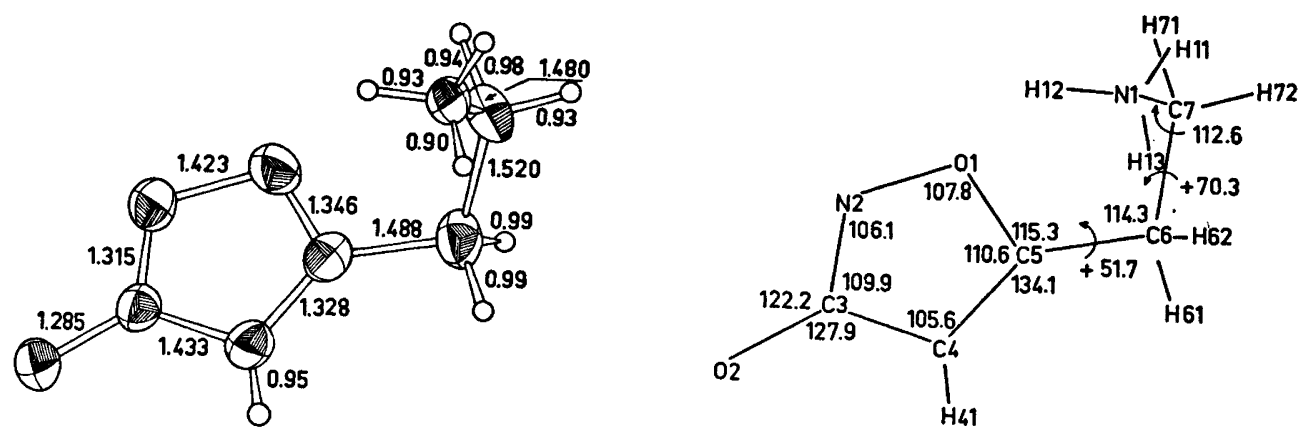

Fig. 2. (a) Bond lengths $(\AA)$, and thermal ellipsoids for the non-hydrogen atoms drawn to enclose $50 \%$ probability. (b) The numbering of the atoms, and some bond angles $\left({ }^{\circ}\right)$ and torsion angles $\left({ }^{\circ}\right)$.

Acta Chem. Scand. B 28 (1974) No. 3 
Table 2. Intra-molecular distances $(\AA)$. The estimated standard deviations $\left(\times 10^{2}\right.$ for bonds to hydrogen, $\times 10^{3}$ for others) of the distances are given in parentheses.

\begin{tabular}{llll}
$\mathrm{O}(1)-\mathrm{N}(2)$ & $1.423(2)$ & $\mathrm{C}(6)-\mathrm{H}(61)$ & $0.99(2)$ \\
$\mathrm{N}(2)-\mathrm{C}(3)$ & $1.315(2)$ & $\mathrm{C}(6)-\mathrm{H}(62)$ & $0.99(2)$ \\
$\mathrm{C}(3)-\mathrm{C}(4)$ & $1.433(2)$ & $\mathrm{C}(7)-\mathrm{H}(71)$ & $0.98(2)$ \\
$\mathrm{C}(4)-\mathrm{C}(5)$ & $1.328(3)$ & $\mathrm{C}(7)-\mathrm{H}(72)$ & $0.93(2)$ \\
$\mathrm{C}(5)-\mathrm{O}(1)$ & $1.346(2)$ & $\mathrm{N}(1)-\mathrm{H}(11)$ & $0.94(2)$ \\
$\mathrm{C}(5)-\mathrm{C}(6)$ & $1.488(2)$ & $\mathrm{N}(1)-\mathrm{H}(12)$ & $0.93(2)$ \\
$\mathrm{C}(6)-\mathrm{C}(7)$ & $1.520(3)$ & $\mathrm{N}(1)-\mathrm{H}(13)$ & $0.90(2)$ \\
$\mathrm{C}(7)-\mathrm{N}(1)$ & $1.480(3)$ & $\mathrm{N}(1) \ldots \mathrm{N}(2)$ & $4.704(2)$ \\
$\mathrm{C}(3)-\mathrm{O}(2)$ & $1.285(2)$ & $\mathrm{N}(1) \ldots \mathrm{O}(1)$ & $3.617(2)$ \\
$\mathrm{C}(4)-\mathrm{H}(41)$ & $0.95(2)$ & $\mathrm{N}(1) \ldots \mathrm{O}(2)$ & $5.979(2)$ \\
\hline
\end{tabular}

arranged about the nitrogen atom. Their positions correspond to a $10-20^{\circ}$ rotation about the $\mathbf{C}-\mathbf{N}$ bond relative to that for a strictly staggered conformation.

Tables 2 and 3 and Figs. $2 a$ and $2 b$ show the intra-molecular distances and angles found. The bond lengths and angles agree well with their equivalents in other isoxazole compounds. ${ }^{2,7-11}$ Thus, it is evident that there is significant resonance within the isoxazole ring, all the bonds except the $\mathrm{N}-\mathrm{O}$ bond having a significant partial double bond character. The geometry of the aminoethyl side chain does not exhibit unusual
Table 3. Valency angles $\left({ }^{\circ}\right)$. The estimated standard deviations ( $\times 10$ for angles not involving hydrogen) of the angles are given in parentheses.

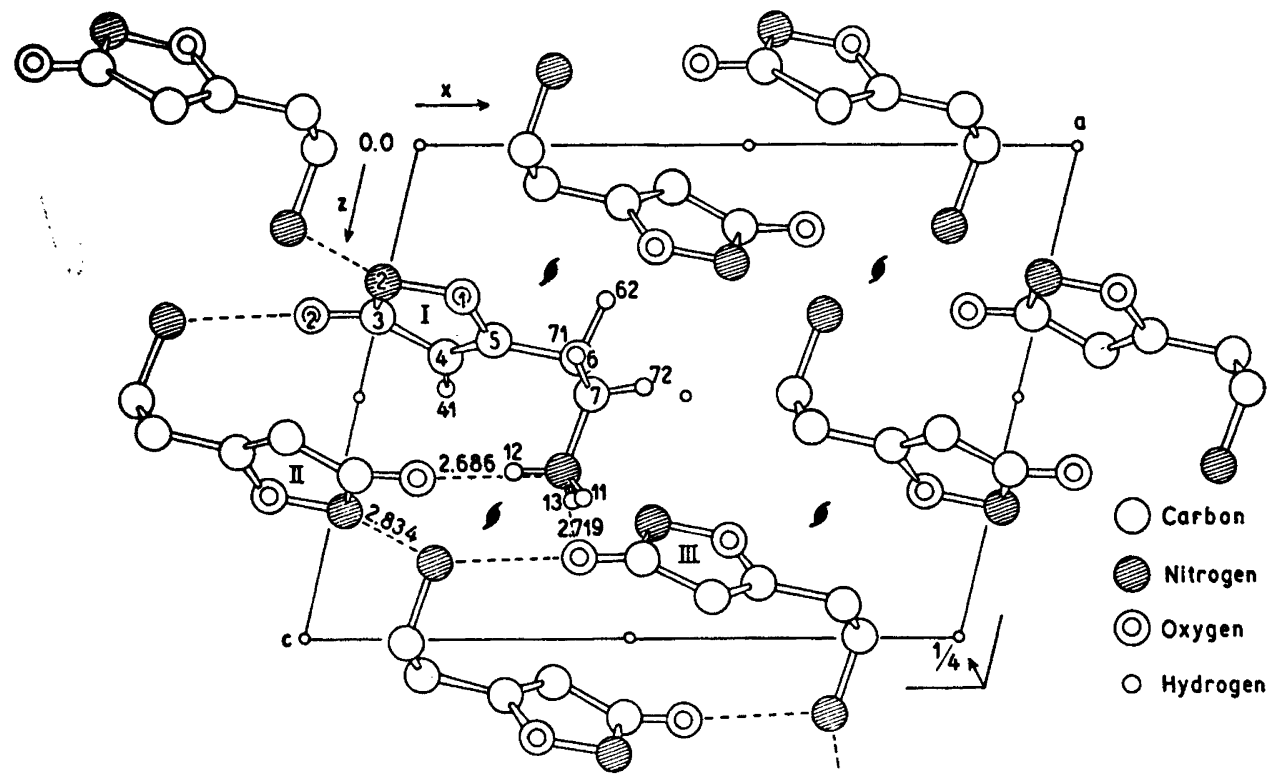

Fig. 3. Projection of the structure down the $b$ axis. Some of the shorter inter-molecular contacts are indicated. 

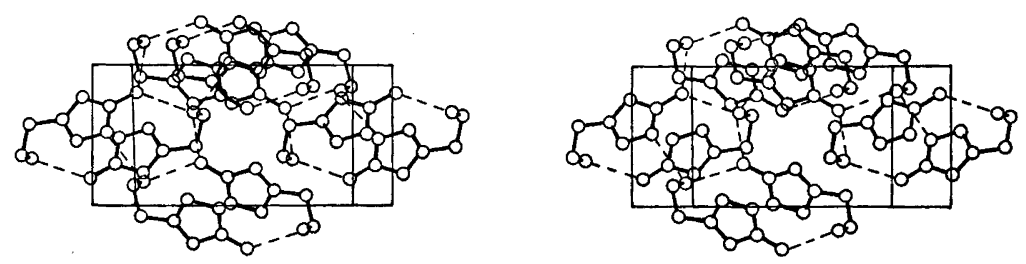

Fig. 4. Stereo diagram illustrating the molecular packing. The view is down $c^{*}$, with $b$ vertical, and $a$ horizontal. Hydrogen bonds are drawn with broken lines.

Table 4. Close inter-molecular contacts involving hydrogen and non-hydrogen atoms.

Distances $(\AA)$ and angles $\left({ }^{\circ}\right)$.

\begin{tabular}{lllllllr}
\hline $\mathrm{A}-\mathrm{H} \cdots \mathrm{B}$ & $\mathrm{B}$ equipoint & $\mathrm{A}-\mathrm{H}$ & $\mathrm{A} \cdots \mathrm{B}$ & $\mathrm{H} \cdots \mathrm{B}$ & $\angle \mathrm{AHB}$ & $\angle \mathrm{HAB}$ & $\angle \mathrm{HBA}$ \\
\hline $\mathrm{N}(1)-\mathrm{H}(11) \cdots \mathrm{N}(2)_{\mathrm{IV}}$ & $\left(\frac{1}{2}+x, 1 \frac{1}{2}-y, \frac{1}{2}+z\right)$ & $0.94(2)$ & $2.834(2)$ & $1.90(2)$ & $173(2)$ & $5(1)$ & $2.3(6)$ \\
$\mathrm{N}(1)-\mathrm{H}(12) \cdots \mathrm{O}(2)_{\mathrm{II}}$ & $(\bar{x}, 1-y, 1-z)$ & $0.93(2)$ & $2.686(2)$ & $1.77(2)$ & $168(2)$ & $8(1)$ & $4.0(6)$ \\
$\mathrm{N}(1)-\mathrm{H}(13) \cdots \mathrm{O}(2)_{\mathrm{III}}$ & $\left(\frac{1}{2}+x, \frac{1}{2}-y, \frac{1}{2}+z\right)$ & $0.90(2)$ & $2.719(2)$ & $1.83(2)$ & $169(2)$ & $7(1)$ & $3.6(6)$ \\
$\mathrm{C}(6)-\mathrm{H}(62) \cdots \mathrm{O}(1)_{\mathrm{V}}$ & $\left(\frac{1}{2}-x,-\frac{1}{2}+y, \frac{1}{2}-z\right)$ & $0.99(2)$ & $3.366(3)$ & $2.68(2)$ & $127(1)$ & $39(1)$ & $13.6(5)$ \\
$\mathrm{C}(7)-\mathrm{H}(72) \cdots \mathrm{N}()_{\mathrm{IV}}$ & $\left(\frac{1}{2}+x, 1 \frac{1}{2}-y, \frac{1}{2}+z\right)$ & $0.93(2)$ & $3.420(2)$ & $3.12(2)$ & $101(1)$ & $64(1)$ & $15.4(4)$ \\
$\mathrm{C}(4)-\mathrm{H}(41) \cdots \mathrm{O}(2)_{\mathrm{VI}}$ & $(\bar{x}, \bar{y}, 1-z)$ & $0.95(2)$ & $3.433(2)$ & $2.53(2)$ & $158(2)$ & $16(1)$ & $5.9(5)$ \\
\hline
\end{tabular}

features. The intra-molecular distance $\mathrm{N}(1)^{+\ldots}$. $\mathrm{O}(2)$ - is $5.979 \AA$.

The anisotropic thermal parameters of the non-hydrogen atoms are given in Table 5 and are drawn schematically in Fig. 2a.

Figs. 3 and 4 illustrate the packing of the homomuscimol molecules in the crystals. The crystal structure is made up of homomuscimol zwitterions and is stabilized by a network of hydrogen bonds, one for each hydrogen atom covalently bonded to nitrogen. Hydrogen bonded pairs result from the formation of bonds $\left[\mathrm{N}(1)-\mathrm{H}(12) \cdots \mathrm{O}(2)_{\mathrm{II}} ; \quad \mathrm{O}(2) \cdots \mathrm{H}(12)_{\mathrm{II}}-\mathrm{N}(1)_{\mathrm{II}}\right]$ between pairs of molecules related by a centre of symmetry. The $n$-glideplane-related molecules are bound head to tail by the hydrogen bond $\mathrm{N}(1)-\mathrm{H}(13) \cdots \mathrm{O}(2)_{\mathrm{III}}$, thereby forming infinite chains in the [101] direction. These chains are connected in the $b$ direction by the hydrogen bond $\mathrm{N}(1)-\mathrm{H}(11) \cdots \mathrm{N}(2)_{\mathrm{IV}}$. Thus, each molecule is involved in six hydrogen bonds to five different neighbouring molecules. A summary of the geometry of the hydrogen bonding between molecules together with a few other close contacts is shown in Table 4.

\section{EXPERIMENTAL}

The determination of melting points, the recording of IR, UV, and ${ }^{1} \mathrm{H}$ NMR spectra, and the performance of microanalyses were accomplished as described in a previous paper. ${ }^{12}$ The $\mathrm{pH}$ values were measured on a Radiometer $\mathrm{pH}$ meter 26.

The computations were performed on a GIER computer and an IBM 360/75 computer using INDIF ${ }^{13}$ a local version of The N.R.C. $2 A$ Picker Data Reduction Program, ${ }^{14}$ The X-Ray System, ${ }^{15}$ and ORTEP. ${ }^{16}$ The $\mathrm{X}$-ray atomic scattering factors used were those of Cromer and Mann ${ }^{17}$ for oxygen, nitrogen, and carbon, and of Stewart, Davidson, and Simpson ${ }^{18}$ for hydrogen.

\section{Synthesis}

3-Methoxy-5-(N-methoxycarbonyl-2-aminoethyl)isoxazole (II). To a mixture of $1.71 \mathrm{~g} \mathrm{(10}$ mmol) of 3-(3-methoxyisoxazolyl-5)propionic acid (I) ${ }^{19}$ and thionyl chloride $(8 \mathrm{ml}) 0.5 \mathrm{ml}$ of $N, N$-dimethylformamide was added dropwise and with stirring. After stirring for further 2 min the solution was evaporated in vacuo to give an oil, which was extracted with three $6 \mathrm{ml}$ portions of ether. The combined ether phases were evaporated in vacuo to give a brownish oil, which was dissolved in tetrachloromethane $(6 \mathrm{ml})$, and upon addition of $1.27 \mathrm{~g}(11 \mathrm{mmol})$ of trimethylsilyl azide the solution was refluxed for $90 \mathrm{~min}$. After cooling to room temperature $1.60 \mathrm{~g}(50 \mathrm{mmol})$ of methanol were added, and the solution was refluxed for further $90 \mathrm{~min}$. After cooling to room temperature the solution was concentrated in vacuo to give an oil, which was dissolved in ether $(15 \mathrm{ml})$. To the ethereal solution was added with stirring petroleum ether $(5 \mathrm{ml})$ and diatomaceous earth 
$(0.5 \mathrm{~g})$. After filtration the solution was evaporated in vacuo to give $1.7 \mathrm{~g}$ of a crystalline product. Recrystallization (ether-petroleum ether) afforded $1.21 \mathrm{~g}(61 \%)$ of compound (II) as colourless crystals, m.p. $56.5-57.5^{\circ} \mathrm{C}$. (Found: C $48.05 ; \mathrm{H} \mathrm{6.09;} \mathrm{N} 14.04$. Calc. for $\mathrm{C}_{8} \mathrm{H}_{12} \mathrm{~N}_{2} \mathrm{O}_{4}$ : C 47.99; H 6.04; $\mathrm{N} 13.99$ ). $\lambda_{\max } 212 \mathrm{~nm}$ ( $\varepsilon=$ $\left.6.50 \times 10^{3}\right)$. IR data $(\mathrm{KBr}) \mathrm{cm}^{-1}: 3265(\mathrm{~s}, \mathrm{NH})$; 1708 and 1680 (both s, monosubstituted urethane $\mathrm{C}=\mathrm{O}$ ); 1618 and 1560 (both $\mathrm{s}$, isoxazolering). ${ }^{1} \mathrm{H}$ NMR data $\left(\mathrm{CCl}_{4}\right) \delta: 5.8-5.3$ (broadened signal, $1 \mathrm{H}, \mathrm{NH}) ; 5.59(\mathrm{~s}, \mathrm{l} \mathrm{H}, \mathrm{C}=\mathrm{CH}-\mathrm{C})$; 3.83 (s, $\left.3 \mathrm{H}, \mathrm{O}-\mathrm{CH}_{3}\right) ; 3.55\left(\mathrm{~s}, 3 \mathrm{H}, \mathrm{CO}-\mathrm{OCH}_{3}\right.$ ); $3.5-3.2\left(t, 2 \mathrm{H}, \mathrm{NH}-\mathrm{CH}_{2}-\mathrm{CH}_{2}\right) ; 3.0-2.6$ (t, $2 \mathrm{H}, \mathrm{CH}_{2}-\mathrm{CH}_{2}-\mathrm{C}=$ ).

3-Hydroxy-5-(2-aminoethyl)isoxazole hydrobromide (III). A solution of $1.32 \mathrm{~g}(6.6 \mathrm{mmol})$ of (II) in $13 \mathrm{ml}$ of glacial acetic acid containing $43 \%$ of hydrogen bromide was heated in an oil bath (bath temperature: $90^{\circ} \mathrm{C}$ ) for $45 \mathrm{~min}$. After cooling to room temperature the reaction mixture was evaporated in vacuo to give an oil, which was dissolved in methanol $(10 \mathrm{ml})$, filtered and evaporated in vacuo to give an oil, which crystallized after having been dried in vacuo over potassium hydroxide for $1 \mathrm{~h}$. Recrystallization (methanol-ether) gave $1.13 \mathrm{~g}(82 \%)$ of compound (III) as colourless crystals, m.p. $171-173^{\circ} \mathrm{C}$ (decomp.). (Found: C 28.60; H 4.29; $\mathrm{N} 13.33 ; \mathrm{Br}$ 38.20. Calc. for $\mathrm{C}_{5} \mathrm{H}_{8} \mathrm{~N}_{2} \mathrm{O}_{2} \mathrm{Br}$ : C $28.72 ; \mathrm{H} \mathrm{4.34}$; N 13.40; $\mathrm{Br} 38.22)$. $\lambda_{\max } 209 \mathrm{~nm}$ $\left(\varepsilon=7.13 \times 10^{3}\right)$. IR data $(\mathrm{KBr}) \mathrm{cm}^{-1}: 3600-2100$ and 1980 (s and w, respectively, $\mathrm{NH}_{3}{ }^{+}$); 1623 and 1535 (both $\mathrm{s}$, isoxazole-ring). ${ }^{1} \mathrm{H}$ NMR data $\left(\mathrm{DMSO}-d_{6}\right) \delta$ : $11.7-9.7$ (broad signal, $1 \mathrm{H}, \mathrm{OH}$ ); 8.5- 7.4 (broad signal, $3 \mathrm{H}, \mathrm{NH}_{3}{ }^{+}$); 5.95 (s, $1 \mathrm{H}$, $\mathrm{C}=\mathrm{CH}-\mathrm{C}) ; 3.4-2.6\left(\mathrm{~m}, 4 \mathrm{H}, \mathrm{NH}_{3}{ }^{+}-\mathrm{CH} \mathrm{H}_{2}-\right.$ $\mathrm{CH}_{2}$ and $\left.\mathrm{CH}_{2}-\mathrm{CH}_{2}-\mathrm{C}=\right)$.

3-Hydroxy-5-(2-aminoethyl)isoxazole zwitterion (IV). $1.48 \mathrm{~g}(7.1 \mathrm{mmol})$ of (III) were dissolved in water $(10 \mathrm{ml})$ and passed through a column containing an ion exchange resin (Amberlite IRA 400, (OH), $130 \mathrm{ml}$ ) using acetic acid $(1 \mathrm{~N})$ as an eluent. The fractions containing compound (IV) were collected and evaporated to dryness in vacuo. The residue was dissolved in water $(10 \mathrm{ml})$ and the solution was treated with a mixture of activated charcoal and diatomaceous earth, filtered, and evaporated in vacuo to give an oil. Crystallization from water-ethanol gave $564 \mathrm{mg}(62 \%)$ of homomuscimol (IV) as colourless crystals, m.p. $167^{\circ} \mathrm{C}$ (decomp.) [Ref. 5, m.p. $158-160^{\circ} \mathrm{C}$ (decomp.)]. $\lambda_{\max } 210 \mathrm{~nm}$ $\left(\varepsilon=6.05 \times 10^{3}\right)$. The IR spectrum is identical with that of a sample prepared according to the method described by Bowden et al. ${ }^{5}$

Determination of the stoichiometric $K_{\mathrm{A}}$ values

The stoichiometric $\mathrm{p} K_{\mathrm{A}}$ values of homomuscimol (IV) have been determined according to the method described by Albert and Serjeant. ${ }^{20}$
Solutions of homomuscimol hydrobromide (III) $0.005 \mathrm{M}$ and of homomuscimol (IV) 0.005 M were titrated with $0.1 \mathrm{~N}$ sodium hydroxide. $\mathrm{pH}$ Values were recorded after nine different additions of titrant between 10 and $80 \%$ of neutralization, and the $\mathrm{p} K_{\mathrm{A}}$ values were calculated using the formula:

$\mathrm{p} K_{\mathrm{A}}=\mathrm{pH}-\log \frac{[\text { Base }]+\left[\mathrm{H}^{+}\right]-\left[\mathrm{OH}^{-}\right]}{[\text {Acid }]-\left[\mathrm{H}^{+}\right]+\left[\mathrm{OH}^{-}\right]}$

[Base] $=$ the stoichiometric concentration of base, $[$ Acid] = the stoichiometric concentration of acid. The final average stoichiometric $\mathrm{p} K_{\mathrm{A}}$ values for homomuscimol (IV) are $5.12 \pm 0.03$ and $9.46 \pm 0.02$.

\section{$X-R$ ay analysis}

The homomuscimol used for the X-ray examination was recrystallized by diffusion at room temperature of absolute ethanol into an aqueous solution of the compound. Colourless prisms somewhat elongated in the $c$ direction were formed.

Crystal data. 3-Hydroxy-5-(2-aminoethyl)isoxazole (homomuscimol), $\mathrm{C}_{5} \mathrm{H}_{8} \mathrm{~N}_{2} \mathrm{O}_{2}, \mathrm{M}=128.14$. Monoclinic, $a=11.530(1), b=6.203(1), c=$ 8.782(2) $\AA, \beta=104.20(1)^{\circ}, U=608.9 \AA^{3}, D_{\mathrm{m}}=$ $1.39 \mathrm{~g} \mathrm{~cm}^{-3}, Z=4, D_{\mathrm{c}}=1.398 \mathrm{~g} \mathrm{~cm}^{-3}$. Linear absorption coefficient for X-rays $[\lambda(\operatorname{MoK} \alpha)=$ $0.7107 \AA], \mu=1.18 \mathrm{~cm}^{-1}$. Number of electrons per unit cell, $F(000)=272$. Systematically absent reflections: $h 0 l$ when $h+l$ odd, $0 k 0$ when $k$ odd; space group $P 2_{1} / n$.

The unit-cell parameters were refined by least-squares techniques from the. diffractometer-measured $\theta$ angles observed for 35 reflections well distributed in reciprocal space. The crystal density was measured by flotation in a chlorobenzene/bromobenzene mixture.

Data collection. Three-dimensional diffraction data were measured at room temperature on a Nonius three-circle automatic diffractometer using graphite monochromated MoK$K \alpha$ radiation. The $\omega$ scan technique with a scan speed of $1.2^{\circ}$ $\min ^{-1}$ was employed. Background counts were taken for half the scanning time at each of the scan range limits. One standard reflection was measured after every 25 reflections.

All the data were measured from a single crystal with approximate dimensions $0.25 \times$ $0.29 \times 0.39 \mathrm{~mm}$. The crystal was mounted with [001] along the $\phi$ axis of the goniostat.

Out of the 1323 independent reflections measured in the range $2.5^{\circ} \leq \theta \leq 27^{\circ}, 996$ had $I_{\text {net }} \geq$ $3.0 \sigma(I)$, where $\sigma(I)$ is the standard deviation from counting statistics. These were regarded as observed reflections, whereas the remaining reflections were regarded as unobserved and excluded from the refinement procedure. Lorentz and polarization corrections were applied, but no absorption corrections were made owing to the low absorption coefficient. 
Table 5. Final positional and thermal $\left(\AA^{2}\right)$ parameters for non-hydrogen atoms.

The estimated standard deviations of positional $\left(\times 10^{4}\right)$ and thermal $\left(\times 10^{2}\right)$ parameters are given in parentheses. The temperature expression is of the form:

\begin{tabular}{|c|c|c|c|c|c|c|c|c|c|}
\hline & $x / a$ & $y / b$ & $z / c$ & $B_{11}$ & $B_{22}$ & $B_{33}$ & $B_{12}$ & $B_{13}$ & $B_{23}$ \\
\hline$O(1)$ & $0.1106(1)$ & $0.5446(2)$ & $0.2984(2)$ & $2.87(6)$ & $3.11(6)$ & $4.87(7)$ & $-0.21(4)$ & $0.29(5)$ & $1.10(5)$ \\
\hline $\mathrm{N}(2)$ & $-0.0115(1)$ & $0.4809(3)$ & $0.2660(2)$ & $2.47(6)$ & $3.24(7)$ & $4.76(8)$ & $0.18(5)$ & $-0.03(5)$ & $0.78(6)$ \\
\hline $\mathrm{C}(3)$ & $-0.0134(1)$ & $0.2956(3)$ & $0.3381(2)$ & $2.38(6)$ & $2.47(7)$ & $2.68(6)$ & $0.07(5)$ & $0.44(5)$ & $-0.46(5)$ \\
\hline C(4) & $0.1061(1)$ & $0.2330(3)$ & $0.4162(2)$ & $2.72(7)$ & $2.54(7)$ & $2.74(6)$ & $0.29(5)$ & $0.38(5)$ & $0.19(5)$ \\
\hline C(5) & $01761(1)$ & $0.3904(3)$ & $0.3880(2)$ & $2.59(6)$ & $2.76(6)$ & $2.25(6)$ & $0.29(5)$ & $0.30(5)$ & $-0.35(5)$ \\
\hline $\mathrm{C}(6)$ & $0.3078(2)$ & $0.4255(3)$ & $0.4278(2)$ & $2.52(7)$ & $3.85(8)$ & $3.43(7)$ & $-0.22(6)$ & $0.70(6)$ & $-0.99(7)$ \\
\hline$C(7)$ & $0.3471(2)$ & $0.6457(3)$ & $0.4973(2)$ & $2.60(7)$ & $3.66(8)$ & $3.43(8)$ & $-0.72(6)$ & $0.77(6)$ & $-0.22(6)$ \\
\hline $\mathrm{N}(1)$ & $0.3303(1)$ & $0.6713(3)$ & $0.6581(2)$ & $2.20(5)$ & $2.45(5)$ & $3.16(6)$ & $-0.10(5)$ & $0.27(4)$ & $-0.26(5)$ \\
\hline$O(2)$ & $-0.1110(1)$ & $0.1927(2)$ & $0.3325(2)$ & $2.49(5)$ & $3.13(6)$ & $4.77(6)$ & $-0.27(4)$ & $0.78(4)$ & $-0.64(5)$ \\
\hline
\end{tabular}

Structure determination. The observed structure amplitudes were brought onto an absolute scale by Wilson statistics and normalized structure amplitudes, $|E(h k l)|$, were calculated.

The phase problem was solved in a straightforward way by direct methods using the programs of the X-Ray System, 1972 edition. $^{16}$

In an $E$ map based on $100 E(h k l)$ 's with $|E(h k l)| \geq 1.5$ the nine highest peaks formed a recognizable molecule and in fact all the peaks corresponded to the positions of the nine nitrogen, oxygen, and carbon atoms. Individual atomic parameters of this model were refined, first with isotropic and then anisotropic thermal parameters using the full-matrix least-squares method. On convergence the $R$ value was 0.084 . The quantity minimized was $\sum w\left(\left|F_{\mathrm{o}}\right|-\left|F_{\mathrm{c}}\right|\right)^{2}$, where weights were initially taken as unity.

A three-dimensional difference Fourier synthesis then showed maxima with peak heights of $0.5-0.7 \Theta \AA^{-3}$ in positions expected for all the hydrogen atoms, and there was no extraneous peaks greater than the lowest hydrogen atom. Introduction of the hydrogen atoms in the refinement, with the isotropic temperature factors of the connected non-hydrogen atoms as constant parameters, reduced the $R$ value to 0.047 .

The least-squares refinement was completed with the introduction of a weighting scheme of the form: $w=1 /\left(1+\left[\left(\left|F_{0}\right|-b\right) / a\right]^{2}\right)$, where $a=3.5 \mathrm{e}$ and $b=6.0 \mathrm{e}$. On the last cycle of least-squares refinement shifts of all the parameters were less than one tenth of their estimated standard deviations and the final $R$ value is 0.042 . Tables 5 and 6 list the final positional and thermal parameters for the non-hydrogen atoms and hydrogen atoms, respectively. From these parameters the terminal set of structure factors, listed with the observed data in Table 7, was computed. Comparison of the 100 signs determined by direct methods with the corresponding phases computed from the refined structure shows that all had been correctly assigned.
Table 6. Final positional and thermal $\left(\AA^{2}\right)$ parameters for hydrogen atoms. The estimated standard deviations $\left(\times 10^{3}\right)$ of the coordinates are given in parentheses.

\begin{tabular}{lllll}
\hline & $x / a$ & $y / b$ & $z / c$ & $B_{\text {iso }}$ \\
\hline $\mathrm{H}(41)$ & $0.122(2)$ & $0.099(3)$ & $0.471(2)$ & 2.6 \\
$\mathrm{H}(61)$ & $0.347(2)$ & $0.306(3)$ & $0.497(2)$ & 3.3 \\
$\mathrm{H}(62)$ & $0.334(2)$ & $0.411(3)$ & $0.329(2)$ & 3.3 \\
$\mathrm{H}(71)$ & $0.303(2)$ & $0.766(3)$ & $0.437(2)$ & 3.2 \\
$\mathrm{H}(72)$ & $0.427(2)$ & $0.671(3)$ & $0.501(2)$ & 3.2 \\
$\mathrm{H}(11)$ & $0.381(2)$ & $0.785(3)$ & $0.702(2)$ & 2.9 \\
$\mathrm{H}(12)$ & $0.251(2)$ & $0.702(3)$ & $0.653(2)$ & 2.9 \\
$\mathrm{H}(13)$ & $0.359(2)$ & $0.557(3)$ & $0.719(2)$ & 2.9 \\
\hline
\end{tabular}

Acknowledgement. This work has been sup. ported by the Danish Medical Research Council. The authors express their gratitude to Professor Bodil Jerslev for her stimulating interest in this work.

\section{REFERENCES}

1. Brehm, L., Hjeds, H. and KrogsgaardLarsen, P. Acta Chem. Scand. 26 (1972) 1298.

2. Brehm, L. To be published.

3. Curtis, D. R., Hösli, L., Johnston, G. A. R. and Johnston, I. H. Exp. Brain Res. 5 (1968) 235.

4. Curtis, D. R., Hösli, L. and Johnston, G. A. R. Exp. Brain Res. 6 (1968) 1.

5. Bowden, K., Crank, G. and Ross, W. J. J. Chem. Soc. Perkin Trans. 1 (1968) 172.

6. Washburne, S. S. and Peterson, W. R., Jr. Syn. Commun. 2 (1972) 227.

7. Cannas, M. and Marongiu, G. Z. Kristallogr. 124 (1967) 143. 
Table \%. Observed structure amplitudes $\left|F_{\mathrm{o}}\right|$ and calculated structure factors $F_{\mathrm{c}}$ (in electrons $\times 10$ ). Within each groups of reflections with constant $k$ and $l$, the columns list, from left to right, $h$, $10\left|F_{\mathrm{o}}\right|$, and $10 F_{\mathrm{c}}$. Reflections considered unobserved are marked with an asterisk.

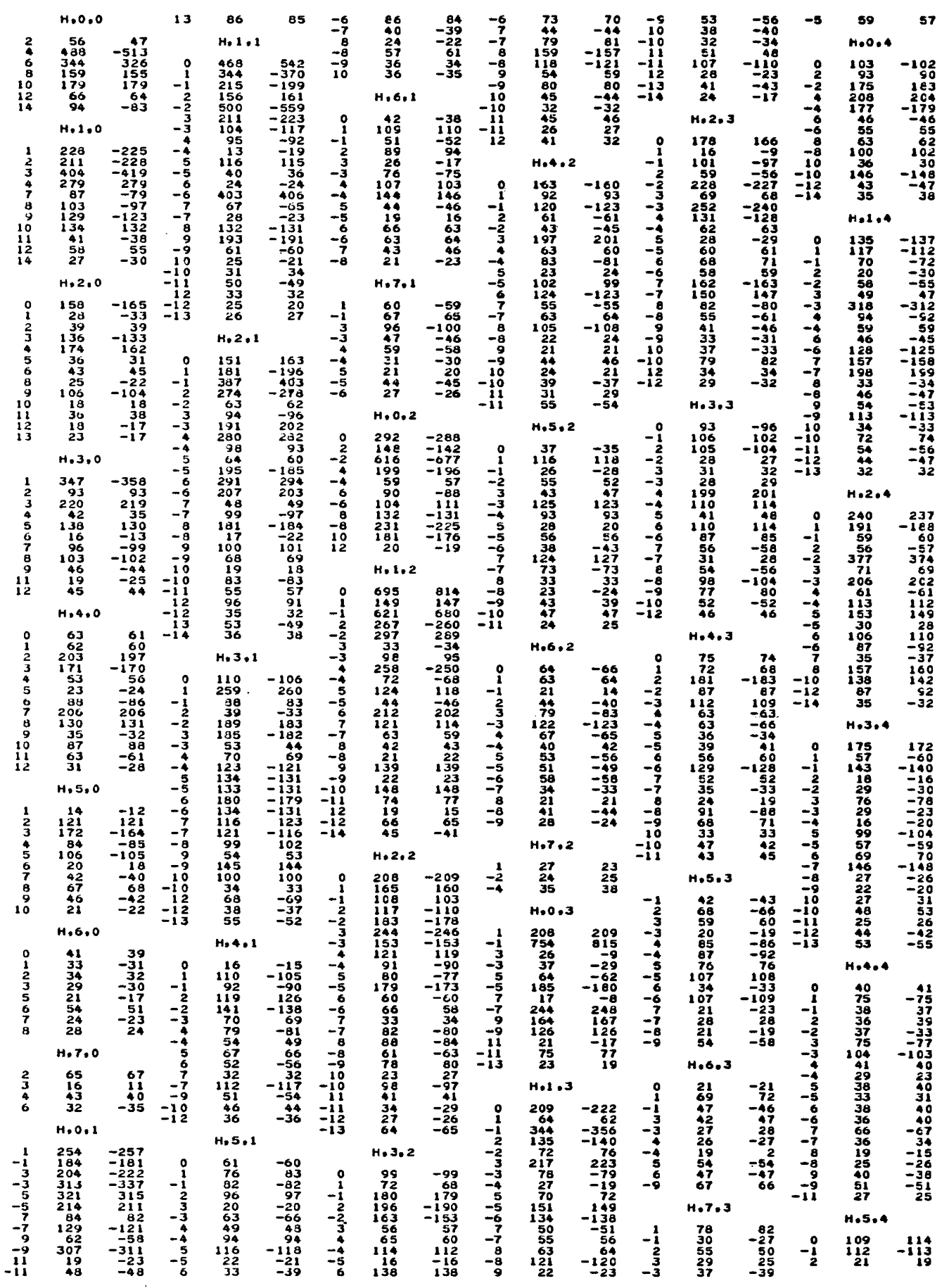

Acta Chem. Scand. B 28 (1974) No. 3 
Table 7. Continued.

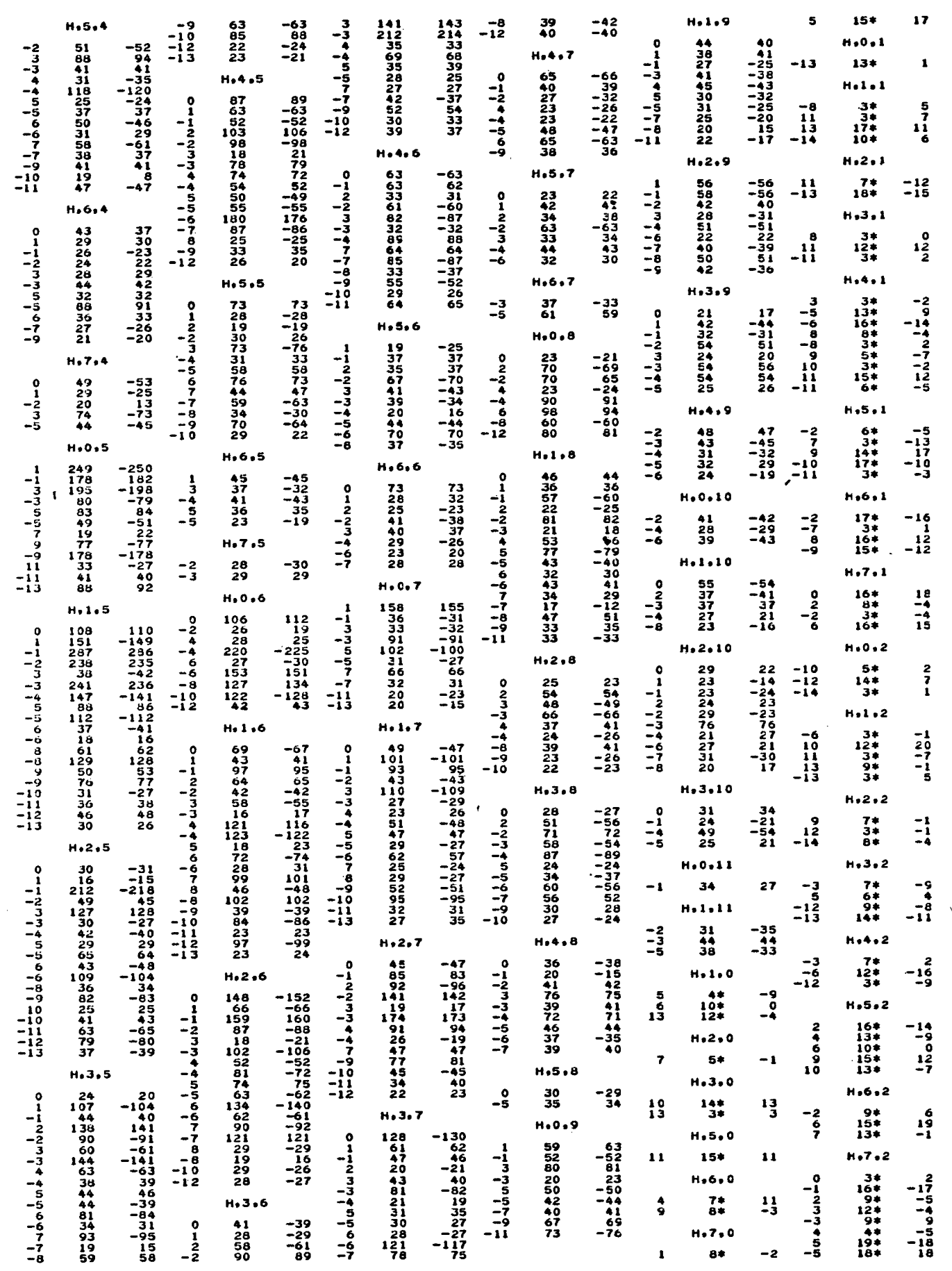

Acta Chem. Scand. B 28 (1974) No. 3 
Table \%. Continued.

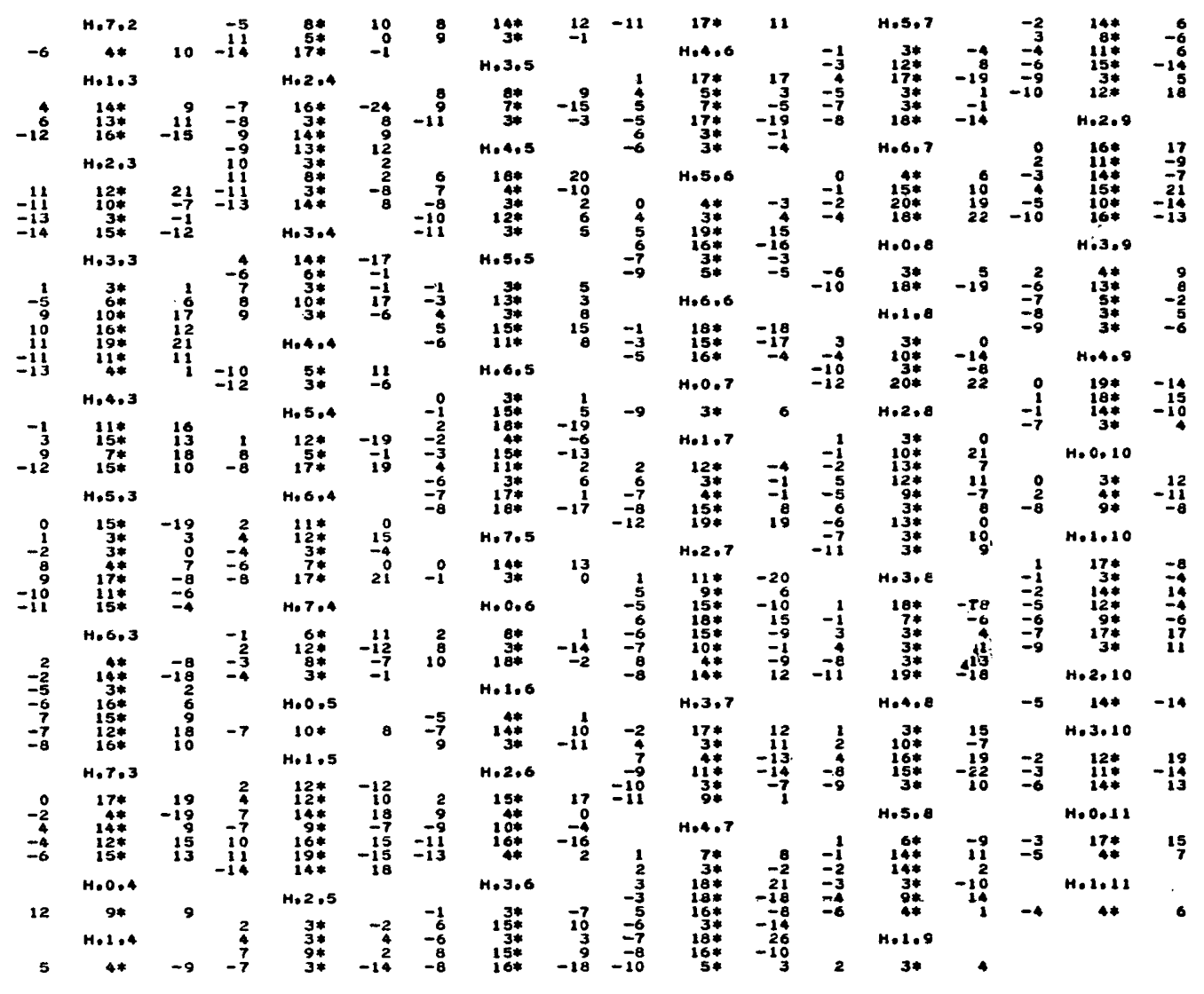

8. Cannas, M. and Marongiu, G. Z. Kristallogr. 127 (1968) 388.

9. Biagini, S., Cannas, M. and Marongiu, G. Acta Crystallogr. B 25 (1969) 730.

10. Biagini, S., Cannas, M. and Marongiu, G. Acta Crystallogr. B 25 (1969) 2108.

11. Biagini, S., Cannas, M. and Marongiu, G. $J$. Heterocycl. Chem. 6 (1969) 901.

12. Krogsgaard-Larsen, P., Christensen, S. B. and Hjeds, H. Acta Chem. Scand. 27 (1973) 2802.

13. Sørensen, A. M. INDIFF, An Algol Nonius Three-Circle Diffractometer Input Data Program, Chemical Laboratory C, The Royal Danish School of Pharmacy, DK-2100 Copenhagen 1968.

14. Ahmed, F. R. N. R. C. Crystallographic Program System, National Research Council Ottawa, Canada 1968.

15. Stewart, J. M., Kruger, G. J., Ammon, H. L., Dickinson, C. and Hall, S. R. X-Ray 72 Crystal Structure Calculation System,
Computer Science Center, University of Maryland, June 1972.

16. Johnson, C. K. ORTEP, A Fortran Thermal Ellipsoid Plot Program for Crystal Structure Illustrations, Oak Ridge, Tennessee 1965.

17. Cromer, D. and Mann, J. Acta Crystallogr. A. 24 (1968) 321.

18. Stewart, R. F., Davidson, E. R. and Simpson, W. T. J. Phys. Chem. 42 (1965) 3175.

19. Thiele, I. and Landers, H. Justus Liebigs Ann. Chem. 369 (1909) 300.

20. Albert, A. and Serjeant, E. P. The Determination of Ionization Constants, Chapmann and Hall, London 1971, p. 9.

Received November 21, 1973.

Acta Chem. Scand. B 28 (1974) No. 3 